\title{
Ketamine, but not priming, improves intubating conditions during a propofol-rocuronium induction
}

\section{La kétamine et non l'amorçage améliore les conditions d'intubation pendant une induction au propofol et au rocuronium}

\author{
Pelin Traje Topcuoglu, MD - Sennur Uzun, MD - Ozgur Canbay, MD • \\ Gulsun Pamuk, MD $\cdot$ Saadet Ozgen, MD
}

Received: 12 May 2009/Accepted: 30 October 2009/Published online: 12 November 2009

(C) Canadian Anesthesiologists' Society 2009

\begin{abstract}
Purpose Both ketamine and priming may shorten the onset time of rocuronium. This study investigates the effects of ketamine and priming as components of a propofol induction on intubating conditions and onset of neuromuscular block.

Methods This prospective randomized double-blind study was performed in 120 American Society of Anesthesiologists (ASA) I-II patients who were assigned to one of four groups of 30 patients each: control, priming, ketamine, and ketamine-priming. Ketamine $0.5 \mathrm{mg} \cdot \mathrm{kg}^{-1} \mathrm{or}$ saline was given before priming and induction. Rocuronium $0.06 \mathrm{mg} \cdot \mathrm{kg}^{-1}$ or saline was injected 2 min before propofol $2.5 \mathrm{mg} \cdot \mathrm{kg}^{-1}$. This was followed by rocuronium $0.6 \mathrm{mg} \cdot \mathrm{kg}^{-1}$ or by rocuronium $0.54 \mathrm{mg} \cdot \mathrm{kg}^{-1}$ if priming was given. Intubation was performed one minute later. Intubating conditions were graded as excellent, good, or poor. Heart rate, noninvasive blood pressure, and train-offour (TOF) response were monitored.

Results Intubating conditions were graded excellent in $20 \%$ of the control group, $30 \%$ of the priming group, $47 \%$ of the ketamine group, and 57\% of the ketamine-priming group. Analysis using forward stepwise regression indicated that ketamine improved intubating conditions $(P=0.001)$ but priming did not $(P=0.35)$. Time to reach a TOF count of zero was shortened by ketamine $(P=0.001)$ but not by priming $(P=0.94): 216 \pm 20 \mathrm{~s}$ in the control group, $212 \pm 27 \mathrm{~s}$ in the priming group,
\end{abstract}

P. T. Topcuoglu, MD · S. Uzun, MD $(\bowtie) \cdot$ O. Canbay, MD . G. Pamuk, MD $\cdot$ S. Ozgen, MD

Department of Anaesthesiology and Reanimation, Faculty of Medicine, Hacettepe University, Sihhıye, Ankara 06100, Turkey

e-mail: sennuruzun@superonline.com
$162 \pm 18 s$ in the ketamine group, and $168 \pm 22 s$ in the ketamine-priming group.

Conclusion A low-dose ketamine used with a propofolrocuronium induction improved intubating conditions and shortened onset time. Priming did not influence intubating conditions or onset time.

\section{Résumé}

Objectif La kétamine et l'amorçage peuvent raccourcir le délai d'action du rocuronium. Cette étude explore les effets de la kétamine et de l'amorçage en tant que composantes d'une induction au propofol sur les conditions d'intubation et le debut du bloc neuromusculaire.

Méthode Cette étude prospective randomisée à double insu a été réalisée chez 120 patients ASA I-II (American Society of Anesthesiologists) affectés à l'un des quatre groupes de 30 patients suivants: témoin, amorçage, kétamine, et kétamine + amorçage. Avant l'amorçage et l'induction, on a administré de la kétamine $0,5 \mathrm{mg} \cdot \mathrm{kg}^{-1} \mathrm{ou}$ du sérum physiologique. Du rocuronium $0,06 \mathrm{mg} \cdot \mathrm{kg}^{-1} \mathrm{ou}$ du sérum physiologique a été injecté 2 min avant l'administration de $2,5 \mathrm{mg} \cdot \mathrm{kg}^{-1}$ propofol. Ensuite, on a administré du rocuronium $0,6 \mathrm{mg} \cdot \mathrm{kg}^{-1}$ ou du rocuronium $0,54 \mathrm{mg} \cdot \mathrm{kg}^{-1} \mathrm{~s}^{\prime} \mathrm{il}$ y avait amorçage. L'intubation a été réalisée une minute plus tard. Les conditions d'intubation ont été définies comme excellentes, bonnes ou mauvaises. La fréquence cardiaque, la tension artérielle non invasive et la réponse au train-de-quatre ont été surveillées.

Résultats Les conditions d'intubation ont été évaluées comme excellentes chez $20 \%$ des patients du groupe témoin, $30 \%$ du groupe amorçage, $47 \%$ du groupe kétamine et $57 \%$ du groupe kétamine + amorçage. Une analyse à l'aide d'une méthode de régression ascendante a indiqué que la kétamine améliorait les conditions d'intubation $(P=0,001)$, mais pas l'amorçage $(P=0,35)$. Le 
temps jusqu'à obtention d'un train-de-quatre de 0 était réduit avec la kétamine $(P=0,001)$ mais pas avec l'amorçage $(P=0,94): 216 \pm 20 \mathrm{sec}$ dans le groupe témoin, $212 \pm 27 \mathrm{sec}$ dans le groupe amorçage, $162 \pm 18 \mathrm{sec}$ dans le groupe kétamine, et $168 \pm 22 \mathrm{sec}$ dans le groupe kétamine + amorçage.

Conclusion Une faible dose de kétamine utilisée lors d'une induction au propofol-rocuronium a amélioré les conditions d'intubation et raccourci le délai d'action du médicament. L'amorçage n'influence ni les conditions d'intubation ni le délai d'action.

\section{Introduction}

Rocuronium provides suboptimal intubating conditions in $20-25 \%$ of patients. ${ }^{1}$ The onset time of a neuromuscular blocking drug is an important factor in determining the speed and ease with which the trachea can be intubated during a rapid sequence induction (RSI). Rocuronium may be an alternative to succinylcholine for RSI whenever succinylcholine is contraindicated. ${ }^{1-3}$ Nevertheless, speed of onset of rocuronium is dose-dependent and high doses are associated with a long duration of action. ${ }^{4}$

Onset time of a nondepolarizing neuromuscular blocking drug may be shortened by priming, i.e., the administration of a small dose of the drug before the larger intubating dose. ${ }^{5}$ In some studies, priming with rocuronium has been found to shorten onset time when compared with a single intubating dose of rocuronium. ${ }^{6}$ In circumstances where a patient has a full stomach and RSI is needed, a priming technique or a high dose $(>2 \times$ effective dose $95 \%$ or $\mathrm{ED}_{95}$ ) of a non-depolarizing neuromuscular blocker has been proposed to accelerate vocal cord opening. ${ }^{3}$

The onset of action is influenced by the speed with which neuromuscular blocking agents are delivered to the neuromuscular junction. This time interval appears to be inversely proportional to cardiac output and muscle blood flow. ${ }^{7}$ Studies that focused on induction agents that maintain cardiac output and blood pressure (e.g., etomidate, ketamine) suggest that the use of these drugs is associated with faster onset times and better intubating conditions. ${ }^{8-10}$ Ketamine has been reported to be associated with better intubating conditions than thiopental. ${ }^{9}$

In studies of simulated RSI with rocuronium, propofol is the preferred induction drug as it improves intubating conditions compared with thiopental. The efficacy of rocuronium for RSI is influenced by both the induction agent and the intubation model. ${ }^{11,12} \mathrm{We}$ hypothesized that the addition of ketamine to a propofol induction would improve intubating conditions after rocuronium while shortening the onset time of neuromuscular block. We also tested whether this could be improved further by the addition of priming. For this, we planned a study to show the effects of both priming and low-dose ketamine on the intubating conditions and onset time of rocuronium block.

\section{Materials and methods}

After ethics committee approval and written informed consent, this prospective randomized double-blind study was carried out in ASA I-II patients who were scheduled for elective nasal surgery requiring general anesthesia. Patients who were judged to be at risk of pulmonary aspiration or anticipated airway difficulty were excluded. All patients were free of pulmonary, neuromuscular, cardiovascular, renal, hepatic, or endocrine disease and were not taking medication known to interact with neuromuscular blocking agents.

No premedication was given. A 20 gauge cannula was inserted into a vein in the dorsum of the hand and connected to an isotonic saline solution. Heart rate, noninvasive blood pressure, and peripheral oxygen saturation were monitored. Values were recorded at baseline, after induction, and every minute for $5 \mathrm{~min}$ after intubation. Neuromuscular monitoring was provided by the $\mathrm{S} / 5^{\mathrm{TM}}$ neuromuscular transmission module (M-NMT) (Datex-Ohmeda, Madison, WI, USA) applied to the adductor pollicis muscle, which delivers electrical impulses to the ulnar nerve and measures the muscle response with the mechanosensor attached to the thumb and index finger. The module finds supramaximal stimulus current in the range from 10 to $70 \mathrm{~mA}$ required to activate the muscle fibers. After injection of propofol, trainof-four (TOF) stimulation was applied every $10 \mathrm{~s}$ until a TOF count of zero was obtained. The time between rocuronium injection and a TOF of zero was measured by a single investigator (S.U.) using a stop watch.

A computer-generated random number table was used to randomly assign the patients to one of four groups of 30 patients each, i.e., according to whether ketamine $0.5 \mathrm{mg} \cdot \mathrm{kg}^{-1}$ or saline was given and whether a priming dose of rocuronium $0.06 \mathrm{mg} \cdot \mathrm{kg}^{-1}$ or saline was administered (Table 1). The medications were prepared by a single investigator (OC) who did not grade intubating conditions. The priming interval was $2 \mathrm{~min}$. All patients received propofol $2.5 \mathrm{mg} \cdot \mathrm{kg}^{-1}$ at induction and a total dose of rocuronium of $0.6 \mathrm{mg} \cdot \mathrm{kg}^{-1}$. One minute after rocuronium was injected, a single anesthesiologist (P.T.) who was unaware of the drugs administered performed tracheal intubation using a Macintosh \# 3 blade. The intubating conditions were evaluated by rating ease of laryngoscopy, position and movement of the vocal cords, and reaction to intubation according to the criteria established by Fuchs-Buder et al. ${ }^{13}$ (Table 2). The quality of 
Table 1 Order of drug injections

\begin{tabular}{|c|c|c|c|c|}
\hline & $\begin{array}{l}\text { 1st injection } \\
(5 \mathrm{~mL})\end{array}$ & $\begin{array}{l}\text { 2nd injection } \\
(5 \mathrm{~mL})\end{array}$ & $\begin{array}{l}\text { 3rd injection } \\
(2 \text { min after the } \\
2 \text { nd drug, in } 30 \mathrm{~s})\end{array}$ & 4th injection \\
\hline Control group & Normal saline & Normal saline & Propofol $2.5 \mathrm{mg} \cdot \mathrm{kg}^{-1}$ & Rocuronium $0.6 \mathrm{mg} \cdot \mathrm{kg}^{-1}$ \\
\hline Priming group & Normal saline & Rocuronium $0.06 \mathrm{mg} \cdot \mathrm{kg}^{-1}$ & Propofol $2.5 \mathrm{mg} \cdot \mathrm{kg}^{-1}$ & Rocuronium $0.54 \mathrm{mg} \cdot \mathrm{kg}^{-1}$ \\
\hline Ketamine group & Ketamine $0.5 \mathrm{mg} \cdot \mathrm{kg}^{-1}$ & Normal saline & Propofol $2.5 \mathrm{mg} \cdot \mathrm{kg}^{-1}$ & Rocuronium $0.6 \mathrm{mg} \cdot \mathrm{kg}^{-1}$ \\
\hline Ketamine-priming group & Ketamine $0.5 \mathrm{mg} \cdot \mathrm{kg}^{-1}$ & Rocuronium $0.06 \mathrm{mg} \cdot \mathrm{kg}^{-1}$ & Propofol $2.5 \mathrm{mg} \cdot \mathrm{kg}^{-1}$ & Rocuronium $0.54 \mathrm{mg} \cdot \mathrm{kg}^{-1}$ \\
\hline
\end{tabular}

Table 2 Assessment of intubating conditions (according to Fuchs-Buder et al. ) $^{13}$

\begin{tabular}{llll}
\hline Variables & Excellent & Good & Poor \\
\hline & Easy & Fair & Difficult \\
Ease of laryngoscopy & Jaw relaxed; no resistance to blade & Jaw not fully relaxed; slight resistance & Poor jaw relaxation; active resistance \\
$\begin{array}{l}\text { Position and movement } \\
\text { Position }\end{array}$ & Abducted & & \\
Movement & None & Intermediate & Closed \\
$\begin{array}{l}\text { Reaction to intubation } \\
\text { Moving of limbs }\end{array}$ & None & Moving & Closing \\
Coughing & None & Slight & Vigorous \\
\hline
\end{tabular}

intubating conditions was rated as excellent when all parameters were scored as excellent, as good when all parameters were considered either excellent or good, and as poor when any parameter was rated as poor.

To avoid vocal cord injury, tracheal intubation was not attempted if the vocal cords were fully closed, in which case, intubation was reattempted $30 \mathrm{~s}$ later. Anesthesia was maintained with $50 \%$ nitrous oxide in oxygen and desflurane. Additional doses of rocuroniun were added at the discretion of the anesthesiologist.

\section{Statistical analysis}

The primary endpoint of this study was the incidence of excellent intubating conditions. Secondary outcomes were onset time to TOF count of zero, heart rate, and mean blood pressure. Statistical analysis was performed using forward stepwise regression using intubating conditions or onset time as the dependent variable and ketamine and priming as independent variables. It was calculated that 28 patients per group were required with a 0.05 level of significance and $90 \%$ power to detect at least a $50 \%$ difference between the control group and any of the other three groups with respect to excellent intubating conditions. All statistical analyses were performed using the Statistical Package for the Social Sciences (SPSS 9.05 for Windows; SPSS Inc., Chicago, IL, USA). Differences among groups were analyzed by nonparametric analysis of variance (ANOVA). Two-way ANOVA, forward stepwise regression, and Kruskal-Wallis were used where appropriate, followed by the Mann-Whitney $U$ test when significant. A $P$ value of 0.05 was considered a statistically significant difference.

\section{Results}

A total of 128 patients were enrolled in the study. Four patients with an anticipated difficult airway, one patient with asthma, and three patients undergoing an emergency operation were excluded. Statistical analysis was performed using the data of the remaining 120 patients. Demographic data were similar in all four groups (Table 3).

Analysis of the intubating conditions using forward stepwise regression showed that intubation conditions were better in the ketamine groups (ketamine group and ketamine-priming group) than in the other groups $(P=0.001)$ (Fig. 1), while priming did not modify intubating conditions significantly $(P=0.35)$. There were no significant differences between groups with respect to reaction to laryngoscopy and position of the vocal cords. Differences were observed with respect to movement of limbs and coughing in response to intubation (Table 4). No signs of neuromuscular block after the administration of the priming dose were observed in any of the groups.

The time for disappearance of all four twitches of trainof-four stimulus (time to reach TOF count of zero) was statistically shorter in the ketamine groups (ketamine group and ketamine-priming group) than in the other groups $(P=0.001): 216 \pm 18 \mathrm{~s}$ in the control group, $212 \pm 27 \mathrm{~s}$ in the priming group, $162 \pm 26 \mathrm{~s}$ in the ketamine group, and 
Table 3 Demographic characteristics

\begin{tabular}{lllll}
\hline & $\begin{array}{l}\text { Control group } \\
(n=30)\end{array}$ & $\begin{array}{l}\text { Priming group } \\
(n=30)\end{array}$ & $\begin{array}{l}\text { Ketamine group } \\
(n=30)\end{array}$ & $\begin{array}{l}\text { Ketamine-priming group } \\
(n=30)\end{array}$ \\
\hline Age $(\mathrm{yr})$ & $34 \pm 15$ & $35 \pm 10$ & $34 \pm 12$ & $32 \pm 9$ \\
Men/women & $18 / 12$ & $16 / 14$ & $13 / 17$ & $15 / 15$ \\
Weight $(\mathrm{kg})$ & $71 \pm 11$ & $70 \pm 14$ & $66 \pm 11$ & $68 \pm 10$ \\
Height $(\mathrm{cm})$ & $168 \pm 8$ & $169 \pm 11$ & $169 \pm 7$ & $169 \pm 8$ \\
\hline
\end{tabular}

Data are expressed as numbers for gender and as mean \pm standard deviation (SD) for age, weight, and height

Fig. 1 Distribution of intubating conditions among four groups of 30 patients each. * $P=0.001$ ketamine and ketamine-priming groups compared with the other two groups, ** $P=0.001$ control group compared with ketamine and ketamine-priming group

Table 4 Intubating conditions of 120 patients

Data are expressed as number of patients

$* P=0.002$ ketamine group compared with control group; ** $P \leq 0.002$ ketamine and ketamine-priming groups compared with control group

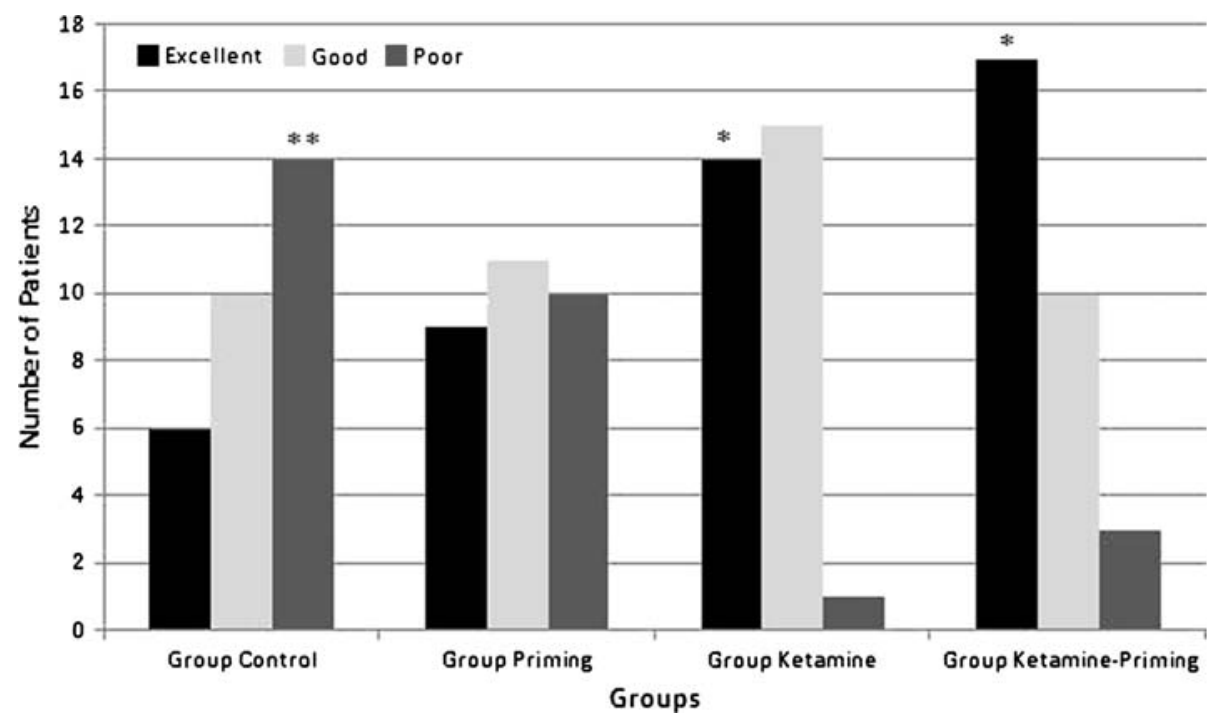

\begin{tabular}{|c|c|c|c|c|}
\hline Variables & $\begin{array}{l}\text { Control group } \\
(n=30)\end{array}$ & $\begin{array}{l}\text { Priming group } \\
(n=30)\end{array}$ & $\begin{array}{l}\text { Ketamine group } \\
(n=30)\end{array}$ & $\begin{array}{l}\text { Ketamine-priming group } \\
(n=30)\end{array}$ \\
\hline \multicolumn{5}{|c|}{ Ease of laryngoscopy } \\
\hline Easy & 21 & 19 & 23 & 27 \\
\hline Fair & 9 & 9 & 7 & 3 \\
\hline Difficult & 0 & 2 & 0 & 0 \\
\hline \multicolumn{5}{|c|}{ Position of vocal cords } \\
\hline Abducted & 19 & 24 & 26 & 26 \\
\hline Intermediate & 10 & 5 & 4 & 3 \\
\hline Closed & 1 & 1 & 0 & 1 \\
\hline \multicolumn{5}{|c|}{ Movement of vocal cords } \\
\hline None & 23 & 25 & 27 & 29 \\
\hline Moving & 6 & 5 & 3 & 0 \\
\hline Closing & 1 & 0 & 0 & 1 \\
\hline \multicolumn{5}{|c|}{ Moving of limbs* } \\
\hline None & 10 & 17 & 25 & 26 \\
\hline Slight & 8 & 4 & 5 & 2 \\
\hline Vigorous & 12 & 9 & 0 & 2 \\
\hline \multicolumn{5}{|l|}{ Coughing** } \\
\hline None & 7 & 19 & 21 & 18 \\
\hline Diaphragm & 16 & 7 & 9 & 11 \\
\hline Sustained & 7 & 4 & 0 & 1 \\
\hline
\end{tabular}




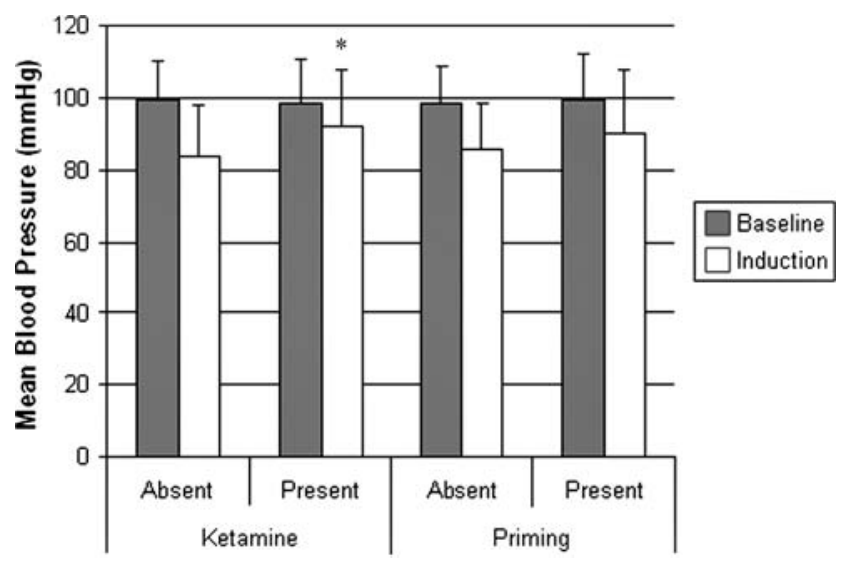

Fig. 2 Mean blood pressure changes of 120 patients before (baseline) and after induction. $* P=0.001$

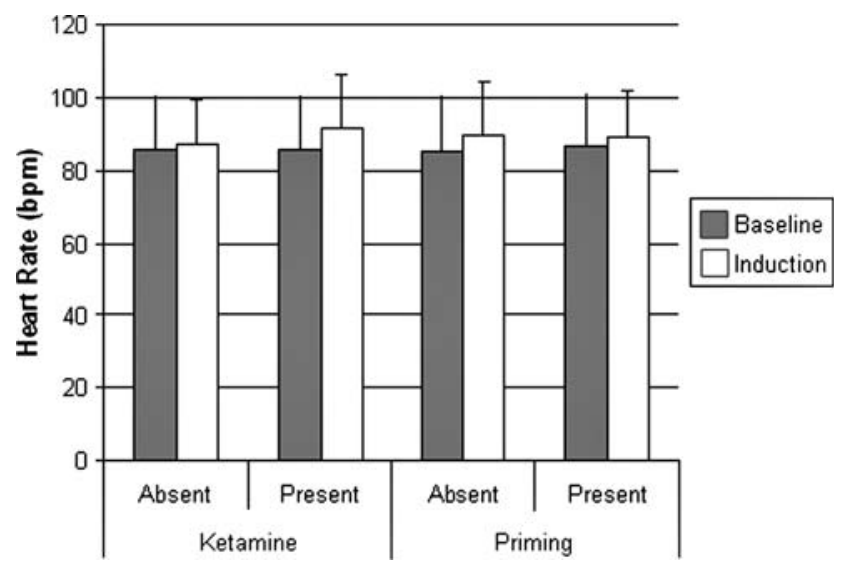

Fig. 3 Heart rate changes of 120 patients before induction (baseline) and after induction

$168 \pm 22 \mathrm{~s}$ in the ketamine-priming group. The effect of ketamine and priming on the onset time of rocuronium was investigated using two-way ANOVA. Ketamine was found to be significantly associated with decreased onset times $(P=0.001)$, while priming had neither a principal effect $(P=0.94)$ nor an interaction with ketamine $(P=0.73)$.

In the ketamine groups, the decrease in mean blood pressure after induction was found to be significantly less than in the other two groups (control and priming) $(P=0.001)$ (Fig. 2). There was no statistically significant difference in heart rate among the groups $(P=0.095)$ (Fig. 3).

Intubation was reattempted after $30 \mathrm{~s}$ in one patient in the control group and one patient in the priming group.

\section{Discussion}

In this study, the addition of low-dose ketamine $0.5 \mathrm{mg}$. $\mathrm{kg}^{-1}$ to propofol $2.5 \mathrm{mg} \cdot \mathrm{kg}^{-1}$ was shown to improve the intubating conditions provided by rocuronium $0.6 \mathrm{mg} \cdot \mathrm{kg}^{-1}$ and to decrease its onset time.

Intubation time is thought to be dependent on physiological factors, such as the onset of neuromuscular blockade, cardiac output, circulation time, and perfusion of muscles. Induction agents, such as etomidate and ketamine, have been shown to accelerate rocuronium onset time by maintaining cardiac output and blood pressure values, thereby improving intubating conditions. In these studies, higher doses of ketamine enabled faster onset of rocuronium due to increased cardiac output. ${ }^{8,9}$ In the induction phase, Tan et al. ${ }^{14}$ compared the use of a combination of propofol and ephedrine with propofol alone. Intubation was performed one minute after the administration of rocuronium $0.6 \mathrm{mg} \cdot \mathrm{kg}^{-1}$. Better intubating conditions were achieved in the group that used ephedrine. In a similar study, intubating conditions with priming alone, ephedrine alone, and a combination of priming and ephedrine were investigated. Findings demonstrated that the combination group, i.e., the priming-ephedrine combination group, provided better intubating conditions compared with the other groups, i.e., priming only group, ephedrine only group, and control group. ${ }^{15}$ In light of the results of these studies, we investigated ketamine instead of ephedrine due to its sympathomimetic effects. In our study, ketamine was used along with rocuronium priming during induction with propofol, and the results were similar to the mentioned previous study with ephedrine. Intubating conditions in our study were better and the onset time of rocuronium (TOF count zero) was shorter in the ketamine groups than in the priming and control groups. A number of studies have supported the hypothesis that ketamine improves orotracheal intubating conditions compared with thiopental. ${ }^{9,16,17}$ In another study, intubating conditions after $60 \mathrm{~s}$ following administration of $0.6 \mathrm{mg} \cdot \mathrm{kg}^{-1}$ rocuronium were compared with intubating conditions following the combinations of ketamine-etomidate, fentanyl-etomidate, or placebo-etomidate during induction. Better intubating conditions were observed in the ketamine-etomidate group, although the onset time was the same. ${ }^{10}$

The rapid distribution of the neuromuscular blocking agent was related to the hemodynamic stimulation of ketamine. Our results supported that ketamine provides good intubation while decreasing the onset time of rocuronium. Munoz et al. ${ }^{18}$ found a faster onset time for rocuronium $0.6 \mathrm{mg} \cdot \mathrm{kg}^{-1}$ using ephedrine $70 \mu \mathrm{g} \cdot \mathrm{kg}^{-1}$ for co-medication and thiopental for induction of anesthesia. However, a faster distribution of rocuronium was assumed in the effect organ (muscle) without detecting any significant differences in heart rate or blood pressure between groups. In our study, although mean blood pressure in all groups decreased compared with baseline values after induction with propofol, this decrease was less in the 
ketamine groups $(P=0.001)$. Mean blood pressure after induction was higher in the ketamine groups compared with the other groups (control, priming). Heart rate differences between the ketamine and the non-ketamine groups did not achieve statistical significance $(P=0.095)$. We compared baseline and post-induction heart rate and blood pressure before intubation hemodynamic variables as rocuronium must take effect before intubation. These results suggest that the good intubating conditions in the ketamine groups may have been due to ketamine's effect on blood pressure and heart rate causing rapid delivery of the rocuronium to the synaptic cleft. Another possible explanation of the good intubating conditions in the ketamine and ketamine-priming group may be that ketamine's analgesic and hypnotic effects provide deep anesthesia and obtund airway reflexes. ${ }^{16}$ In our study, the dose of propofol was not reduced in patients receiving ketamine. This may have caused a synergistic effect between propofol and ketamine causing deep anesthesia favouring intubating conditions. ${ }^{19}$ No hypotension or any side effects were seen; however, future studies involving decreased doses of propofol in groups receiving ketamine and equi-anesthetic doses of the drugs could be planned.

The assessment of intubating conditions is a complex task. A standard method was used in our study, and to provide consistency, a single anesthetist (P.T.) who was blinded to the study groups performed all of the intubations.

Since propofol has a high potential for hypotension and bradycardia, adding an opioid to the anesthesia procedure could lead to increased incidence of these effects. A decrease in airway reflexes could be due to ketamine or opioid. For this reason, opioids were not used in the present study. Since opioids are able to blunt laryngeal reflexes, they enable good intubation conditions with or without neuromuscular blocking agents. ${ }^{20}$

It is important to point out that priming may result in muscle weakness, dysphagia, impaired vision, and respiratory failure in the awake patient. Thus, the priming dose, the intubation dose, and the priming interval all play significant roles in the efficacy of the priming technique and in the prevention of probable adverse effects. ${ }^{21,22}$ No adverse effects were reported in recent studies that used a priming dose of rocuronium $0.06 \mathrm{mg} \cdot \mathrm{kg}^{-1}$. ${ }^{6,23,24}$ In the case of higher doses and longer intervals of priming, the incidence of mentioned adverse effects would be higher. A number of studies have demonstrated that priming shortened the onset time of rocuronium. ${ }^{18,19}$ Naguib et al. ${ }^{6}$ showed that an intubating dose of rocuronium $0.54 \mathrm{mg} \cdot \mathrm{kg}^{-1}$ administered after 3 min of a priming dose of rocuronium $0.06 \mathrm{mg}$. $\mathrm{kg}^{-1}$ shortened the onset time of the effect approximately 20-35\% when compared with the administration of rocuronium $0.6 \mathrm{mg} \cdot \mathrm{kg}^{-1}$ as a single dose for intubation. In the present study, we used the same priming dose as in
Naguib's study, i.e., rocuronium $0.06 \mathrm{mg} \cdot \mathrm{kg}^{-1}$ and a priming interval of $2 \mathrm{~min}$, rather than Naguib's 3-min priming period. Our findings are different from Naguib et al.'s, as we did not see an effect of priming on the onset time of rocuronium. We chose a 2 min priming interval because Griffith $e t a l .^{23}$ found a significantly shorter onset time with that priming interval.

Time to reach TOF count of zero may be altered by different induction agents and neuromuscular blockers. ${ }^{15}$ Leykin et $a l .{ }^{15,25}$ studied different induction agents and ephedrine with and without priming and claimed that intubating conditions were better if ephedrine and ketamine were used. However, no differences between groups in terms of onset times or hemodynamic findings were demonstrated. We also found that intubating conditions were improved by ketamine, but contrary to Leykin et al.'s studies, we showed that onset time was shorter in the ketamine groups and associated with a more modest decrease in blood pressure after induction with propofol if ketamine was given.

A limitation of this study was that only the time to reach TOF count zero was recorded. Recording the TOF count one minute after rocuronium priming and at intubation would have provided a more accurate interpretation of the intubating conditions in relation to neuromuscular relaxation. It might be worthwile to plan further studies with different doses of ketamine including detailed TOF records. Another potential weakness is that this study was performed in elective patients not requiring a rapid sequence induction; however, it is clear that it is impossible to conduct a study in patients requiring RSI.

The present study demonstrated that the addition of lowdose ketamine to propofol induction improves intubation conditions by providing good jaw relaxation, better vocal cord abduction, decreased response to intubation, and a shortened onset time of rocuronium. In this study, priming with rocuronium $0.06 \mathrm{mg} \cdot \mathrm{kg}^{-1}$ and a 2 min interval had no effect on the onset time and intubating conditions following rocuronium.

Sources of funding Funding was supported by the Department of Anaesthesiology.

Conflicts of interest None declared.

\section{References}

1. Magorian T, Flannery KB, Miller RD. Comparison of rocuronium, succinylcholine, and vecuronium for rapid-sequence induction of anesthesia in adult patients. Anesthesiology 1993; 79: 913-8.

2. Puhringer FK, Khuenl-Brady KS, Koller J, Mitterschiffthaler G. Evaluation of the endotracheal intubating conditions of rocuronium (ORG 9426) and succinylcholine in outpatient surgery. Anesth Analg 1992; 75: 37-40. 
3. Siddik-Sayyid SM, Taha SK, Kanazi GE, et al. Excellent intubating conditions with remifentanil-propofol and either low-dose rocuronium or succinylcholine. Can J Anesth 2009; 56: 483-8.

4. Engbaek J, Viby-Mogensen J. Can rocuronium replace succinylcholine in a rapid-sequence induction of anaesthesia? Acta Anaesthesiol Scand 1999; 43: 1-3.

5. Miller RD. The priming principle. Anesthesiology 1985; 62: 381-2.

6. Naguib $M$. Different priming techniques, including mivacurium, accelerate the onset of rocuronium. Can J Anaesth 1994; 41: 902-7.

7. Donati F. Onset of action of relaxants. Can J Anaesth 1988; 35: S52-8.

8. Fuchs-Buder T, Sparr HJ, Ziegenfuss T. Thiopental or etomidate for rapid sequence induction with rocuronium. $\mathrm{Br} \mathrm{J}$ Anaesth 1998; 80: 504-6.

9. Hans P, Brichant JF, Hubert B, Dewandre PY, Lamy M. Influence of induction of anaesthesia on intubating conditions one minute after rocuronium administration: comparison of ketamine and thiopentone. Anaesthesia 1999; 54: 276-9.

10. Ledowski $T$, Wulf $H$. The influence of fentanyl vs. s-ketamine on intubating conditions during induction of anaesthesia with etomidate and rocuronium. Eur J Anaesthesiol 2001; 18: 519-23.

11. Taha S, Siddik-Sayyid S, Alameddine $M$, et al. Propofol is superior to thiopental for intubation without muscle relaxants. Can J Anesth 2005; 52: 249-53.

12. Lysakowski J, Suppan L, Czarnetzki C, Tassonyi E, Tramer MR. Impact of the intubation model on the efficacy of rocuronium during rapid sequence intubation: systematic review of randomized trials. Acta Anaesthesiol Scand 2007; 51: 848-57.

13. Fuchs-Buder T, Claudius C, Skovgaard LT, et al. Good clinical research practice in pharmacodynmic studies of neuromuscular blocking agents II: the Stockholm revision. Acta Anaesthesiol Scand 2007; 51: 789-808.

14. Tan CH, Onisong MK, Chiu WK. The influence of induction technique on intubating conditions $1 \mathrm{~min}$ after rocuronium administration: a comparison of a propofol-ephedrine combination and propofol. Anaesthesia 2002; 57: 223-6.
15. Leykin Y, Pellis T, Lucca M, Gullo A. Effects of ephedrine on intubating conditions following priming with rocuronium. Acta Anaesthesiol Scand 2005; 49: 792-7.

16. Reves JG, Glass PS, Lubarsky DA. Nonbarbiturate intravenous anesthetics. In: Miller RD (Ed.). Anesthesia, 5th ed. Philadelphia: Churchill Livingstone; 2000: 228-73.

17. Baraka AS, Sayyid SS, Assaf BA. Thiopental-rocuronium versus ketamine-rocuronium for rapid sequence intubation in parturients undergoing cesarean section. Anesth Analg 1997; 84: 1104-7.

18. Munoz HR, Gonzalez AG, Dagnino JA, Gonzalez JA, Perez AE. The effect of ephedrine on the onset time of rocuronium. Anesth Analg 1997; 85: 437-40.

19. Hendrickx JF, Eger EI II, Sonner JM, Shafer SL. Is synergy the rule? A review of anesthetic interactions producing hypnosis and immobility. Anesth Analg 2008; 107: 494-506.

20. Abou-Arab MH, Heier T, Caldwell JE. Dose of alfentanil needed to obtain optimal intubation conditions during rapid-sequence induction of anaesthesia with thiopentone and rocuronium. Br J Anaesth 2007; 98: 604-10.

21. Schwarz S, Ilias W, Lackner F, Mayrhofer O, Foldes FF. Rapid tracheal intubation with vecuronium: the priming principle. Anesthesiology 1985; 62: 388-91.

22. Mirakhur RK, Lavery GG, Gibson FM, Clarke RS. Intubating conditions after vecuronium and atracurium given in divided doses (the priming technique). Acta Anaesthesiol Scand 1986; 30: 347-50.

23. Griffith KE, Joshi GP, Whitman PF, Garg SA. Priming with rocuronium accelerates the onset of neuromuscular blockade. J Clin Anesth 1997; 9: 204-7.

24. Yavaşçaoğlu B, Cebelli V, Kelebek $N$, Uçkunkaya $N$, Kutlay O. Comparison of different priming techniques on the onset time and intubating conditions of rocuronium. Eur J Anaesthesiol 2002; 19: 517-21.

25. Leykin $Y$, Pellis $T$, Lucca $M$, Gullo A. Intubation conditions following rocuronium: influence of induction agent and priming. Anaesth Intensive Care 2005; 33: 462-8. 